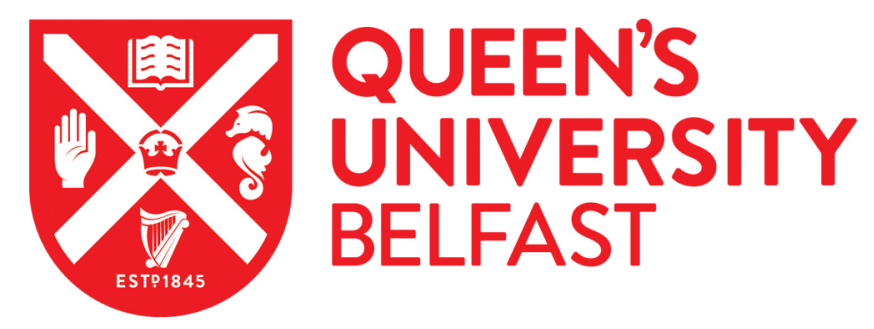

\title{
Stable Isotope Palaeodietary Analysis of the Early Bronze Age Afanasyevo Culture in the Altai Mountains, Southern Siberia
}

Svyatko, S. V., Polyakov, A. V., Soenov, V. I., Stepanova, N. F., Reimer, P. J., Ogle, N., Tyurina, E. A., Grushin, S. P., \& Rykun, M. P. (2017). Stable Isotope Palaeodietary Analysis of the Early Bronze Age Afanasyevo Culture in the Altai Mountains, Southern Siberia. Journal of Archaeological Science Reports, 14, 65-75.

https://doi.org/10.1016/j.jasrep.2017.05.023

Published in:

Journal of Archaeological Science Reports

Document Version:

Peer reviewed version

Queen's University Belfast - Research Portal:

Link to publication record in Queen's University Belfast Research Portal

Publisher rights

Copyright 2018 Elsevier.

This manuscript is distributed under a Creative Commons Attribution-NonCommercial-NoDerivs License

(https://creativecommons.org/licenses/by-nc-nd/4.0/), which permits distribution and reproduction for non-commercial purposes, provided the author and source are cited.

\section{General rights}

Copyright for the publications made accessible via the Queen's University Belfast Research Portal is retained by the author(s) and / or other copyright owners and it is a condition of accessing these publications that users recognise and abide by the legal requirements associated with these rights.

Take down policy

The Research Portal is Queen's institutional repository that provides access to Queen's research output. Every effort has been made to ensure that content in the Research Portal does not infringe any person's rights, or applicable UK laws. If you discover content in the Research Portal that you believe breaches copyright or violates any law, please contact openaccess@qub.ac.uk. 


\section{Title:}

Stable Isotope Palaeodietary Analysis of the Early Bronze Age Afanasyevo Culture in the Altai Mountains, Southern Siberia

Authors: Svetlana V. Svyatko ${ }^{1 *}$, Andrey V. Polyakov ${ }^{2}$, Vasilii I. Soenov ${ }^{3}$, Nadezhda F. Stepanova ${ }^{4,5}$, Paula J. Reimer ${ }^{1}$, Neil Ogle ${ }^{6}$, Ekaterina A. Tyurina ${ }^{4}$, Sergei P. Grushin ${ }^{4}$, Marina P. Rykun $^{7}$

1. ${ }^{14}$ CHRONO Centre for Climate, the Environment, and Chronology, Queen's University of Belfast, Belfast BT7 1NN, Northern Ireland, UK

2. Institute for the History of the Material Culture, Russian Academy of Sciences, 18 Dvortsovaya nab., St Petersburg, 191186, Russia

3. Research Centre for the History and Culture of the Turkic Peoples, Gorno-Altaisk State University, A. Lenkina 1, Gorno-Altaisk 649000, Russia

4. Department of History, Altai State University, Barnaul, Prospekt Lenina 61a, 656049, Russia

5. Institute of Archaeology and Ethnography, Siberian Branch of the Russian Academy of Sciences, Ave. Lavrentiev 17, Novosibirsk 630090, Russia

6. Stable Isotope Facility, School of Natural and Built Environment, Queen's University of Belfast, Belfast BT9 5AG, Northern Ireland, UK

7. Cabinet of Anthropology, Tomsk State University, Prospekt Lenina 36, Tomsk 634050, Russia

* Corresponding Author:

Tel.: +44 (0)2890973974 
E-mail: s.svyatko@qub.ac.uk 